\title{
First Report of a Postharvest Fruit Rot on Apple Caused by Diaporthe phaseolorum var. caulivora in China: A Note
}

\author{
Yuanzhi Chen*, Quan Zhou*, Yangying Sun, Ran Li, Yaoyao Liu, Ting Zhou\# \\ College of Life and Environmental Science, Hangzhou Normal University, Hangzhou, China \\ Email: ${ }^{*}$ zt20100061@163.com
}

How to cite this paper: Chen, Y.Z., Zhou, Q., Sun, Y.Y., Li, R., Liu, Y.Y. and Zhou, T. (2020) First Report of a Postharvest Fruit Rot on Apple Caused by Diaporthe phaseolorum var. caulivora in China: A Note. American Journal of Plant Sciences, 11, 1612-1617.

https://doi.org/10.4236/ajps.2020.1110116

Received: September 3, 2020

Accepted: October 25, 2020

Published: October 28, 2020

Copyright $\odot 2020$ by author(s) and Scientific Research Publishing Inc. This work is licensed under the Creative Commons Attribution International License (CC BY 4.0).

http://creativecommons.org/licenses/by/4.0/

\begin{abstract}
Brown rots of Red Fuji apples were observed in Hangzhou city (Zhengjiang Province, China). The causal agent was isolated and identified in both morphological and molecular genetic levels. The phenotype and phylogenetic analysis revealed that the isolate was Diaporthe phaseolorum var. caulivora, and its pathogenicity on apple fruit was confirmed by re-inoculation experiment. To our knowledge, this is the first report of $D$. phaseolorum var. caulivora causing postharvest fruit rot on apple in China.
\end{abstract}

\section{Keywords}

Apple, Postharvest Pathogen, ITS-rDNA, Diaporthe phaseolorum var. caulivora

\section{Introduction}

Apple (Malus domestica Borkh.) is a kind of popular edible fruit in China and the apple industry is one of the advantageous industries of China's agricultural economy. In 2018, the apple production of China was 39.24 million tonnes accounting for $45.55 \%$ of the world total (http://www.fao.org/faostat/en/\#data/QC). Apple fruit containing high levels of sugars and nutrients was susceptible to fungal infection at suboptimal conditions which lead to serious commercial losses and mycotoxin contamination for some toxigenic fungi [1] [2] [3]. Developing effective methods for controlling fruit rot is based on precise recognition of the pathogenic fungi. The most common causes of apple rot are Penicillium expansum, Rhizopus oryzae, Monilinia fructigena, Colletotrichum, Botryosphaeria, and Xylaria. Aspergillus, Cladosporium, Aureoba-

*Yuanzhi Chen and Quan Zhou contributed equally to this work. 
sidium, Alternaria and Cryptococcus were also found in stored apples [4] [5]. For minor differences in disease symptoms or different ambient conditions, some other pathogens have not been discovered yet. In this study, the pathogenic fungi that caused brown rots of Red Fuji apples was isolated from naturally infected apples and identified through morphological and molecular characterization.

\section{Materials and Methods}

\subsection{Isolation of Pathogen}

Naturally infected apples (Malus domestica Borkh. cv. Red Fuji) were collected from the local supermarket in Jianggan District of Hangzhou City. For the isolation of the causal agent, a small piece (about $0.2 \mathrm{~cm}$ ) of necrotic tissue with the structure of reproduction of fungus was cut from infected apple fruit, disinfected by $75 \%$ ethanol for 2 min followed by rinsing with sterile distilled water, air-dried, plated onto potato dextrose agar (PDA) medium. After 7 days of culturing, hyphal tips were transferred to PDA and cultured at $25^{\circ} \mathrm{C}$ under $16 \mathrm{~h}$ photoperiods with a light intensity of 1500 lux. Repeat this step until the colonial phenotype was stable.

\subsection{Identification of Pathogen}

Morphological characteristics of isolates (conidia, mycelia, colonies, and symptoms) were observed. Also, the total genome DNA of pathogen was extracted from the mycelia by a DNeasy Plant Mini Kit (Qiagen, Germany) following the product manual. The internal transcribed spacer (ITS) of rDNA and $\beta$-tubulin regions were amplified using a PrimeSTAR HS DNA Polymerase (Takara, Japan) and the primer sets ITS1/ITS4

(CTTGGTCATTTAGAGGAAGTAA/TCCTCCGCTTATTGATATGC), TS4/ITS5

(TCCTCCGCTTATTGATATGC/GGAAGGTAAAAGTCGTAACAAG), and BT2a/BT2b

(AACATGCGTGAGATTGTAAGT/TCTGGATGTTGTTGGGAATCC) [6] [7]. The amplified products were sequenced using a service from Sangon Biotech (China) and analyzed online at http://blast.ncbi.nlm.nih.gov/Blast.cgi.

\subsection{Evaluation of Fungal Pathogenicity}

To confirm the pathogenicity, twelves surface-sterilized apples at commercial maturity and without mechanical injury were wounded by a sterile syringe needle. Six apples were inoculated with mycelial plugs $(5 \mathrm{~mm}$ diameter) from 7-day old cultures. As a negative control, six apples were inoculated with sterile PDA plugs. All fruit were incubated in a moist chamber at $25^{\circ} \mathrm{C}$ and $80 \%$ humidity with a $16 \mathrm{~h}$ light $/ 8 \mathrm{~h}$ darkness period. The decay incidence and lesion diameter were recorded. Two replicates were conducted. The pathogens were re-isolated from symptomatic fruits and identified by the steps described above. 


\section{Results and Discussion}

In August 2018, brown rots of "Red Fuji" apples were observed in several supermarkets in Hangzhou city (Zhengjiang Province, China). Early symptoms of fruit rot included light to dark brown lesions with defined margins. In more advanced stages of the disease, the fruit became completely rotten and soft. In the PDA plate, the isolated fungus developed fast and quickly formed a dense white mycelium, which gradually became fluffy. The color of mycelium was white at first, turning light yellow-green on the front and dark brown on the reverse side of plates. After 2 weeks of culturing, black stromata with irregular shapes were visible. The perithecia had a variable-length neck. Conidia were hyaline, round, elongate to ellipsoidal, or irregular (Figure 1).

After amplification using universal primer pairs, DNA fragments about 600 - $700 \mathrm{bp}$ were obtained, sequenced, and mega blasted. MegaBLAST searches against GenBank showed that our sequences best matched with $97.69 \%$ (ITS1/ITS4), 97.69\% (ITS4/ITS5), and 97.60\% (BT2a/BT2b) nucleotide identity to Diaporthe phaseolorum var. caulivora. Phylogenetic analysis revealed that the isolate was clustered within D. phaseolorum var. caulivora (Figure 2), complementing the morphological identification [8]. Thus, the isolate was identified as D. phaseolorum var. caulivora through morphological and molecular characterization. The sequence of amplification products by BT2a/BT2b was deposited in GenBank. Accession No. MK840648

(https://www.ncbi.nlm.nih.gov/nuccore/MK840648). The sequence information of amplification products using primer sets ITS1/ITS4, ITS4/ITS5 and BT2a/BT2b was listed in Table 1.

Table 1. The sequence information of amplification products using the primer sets ITS1/ITS4, ITS4/ITS5, and BT2a/BT2b in Diaporthe phaseolorum var. caulivora.

\begin{tabular}{|c|c|c|}
\hline Primer pairs & Length (bp) & Sequence information \\
\hline ITS1/ITS4 & 619 & 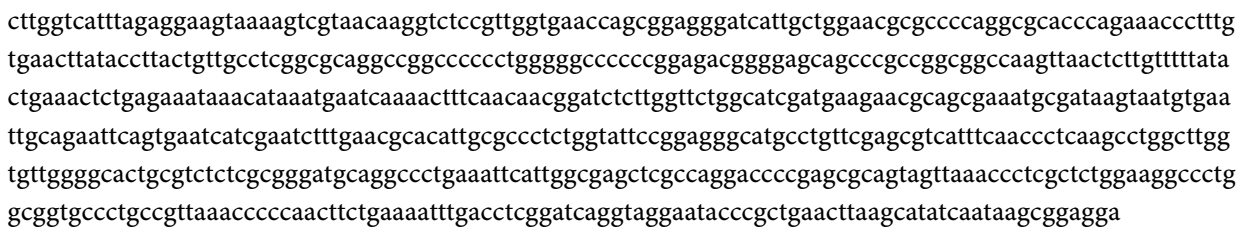 \\
\hline ITS4/ITS5 & 605 & $\begin{array}{l}\text { tcctccgcttattgatatgcttaagttcagcgggtattcctacctgatccgaggtcaaattttcagaagttgggggtttaacggcagggcaccgccagggccttcca } \\
\text { gagcgagggtttaactactgcgctcggggtcctggcgagctcgccaatgaatttcagggectgcatcccgcgagagacgcagtgccccaacaccaagccagg } \\
\text { cttgagggttgaaatgacgctcgaacaggcatgccctccggaataccagagggcgcaatgtgcgttcaaagattcgatgattcactgaattctgcaattcacatt } \\
\text { acttatcgcatttcgctgcgttcttcatcgatgccagaaccaagagatccgttgttgaaagttttgattcatttatgtttatttctcagagtttcagtataaaaacaaga } \\
\text { gttaacttggccgccggcgggctgctccccgtctccggggggccccaggggggccggcctgcgccgaggcaacagtaaggtataagttcacaaagggtttct } \\
\text { gggtgcgcctggggcgcgttccagcaatgatccctccgctggttcaccaacggagaccttgttacgacttttacttcc }\end{array}$ \\
\hline BT2a/BT2b & 705 & 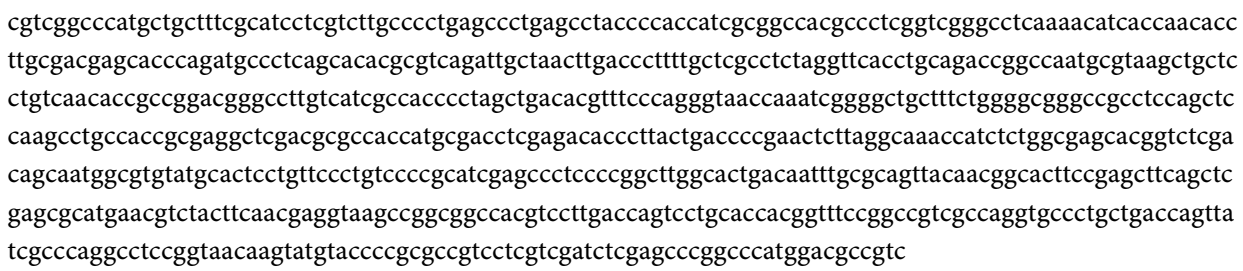 \\
\hline
\end{tabular}



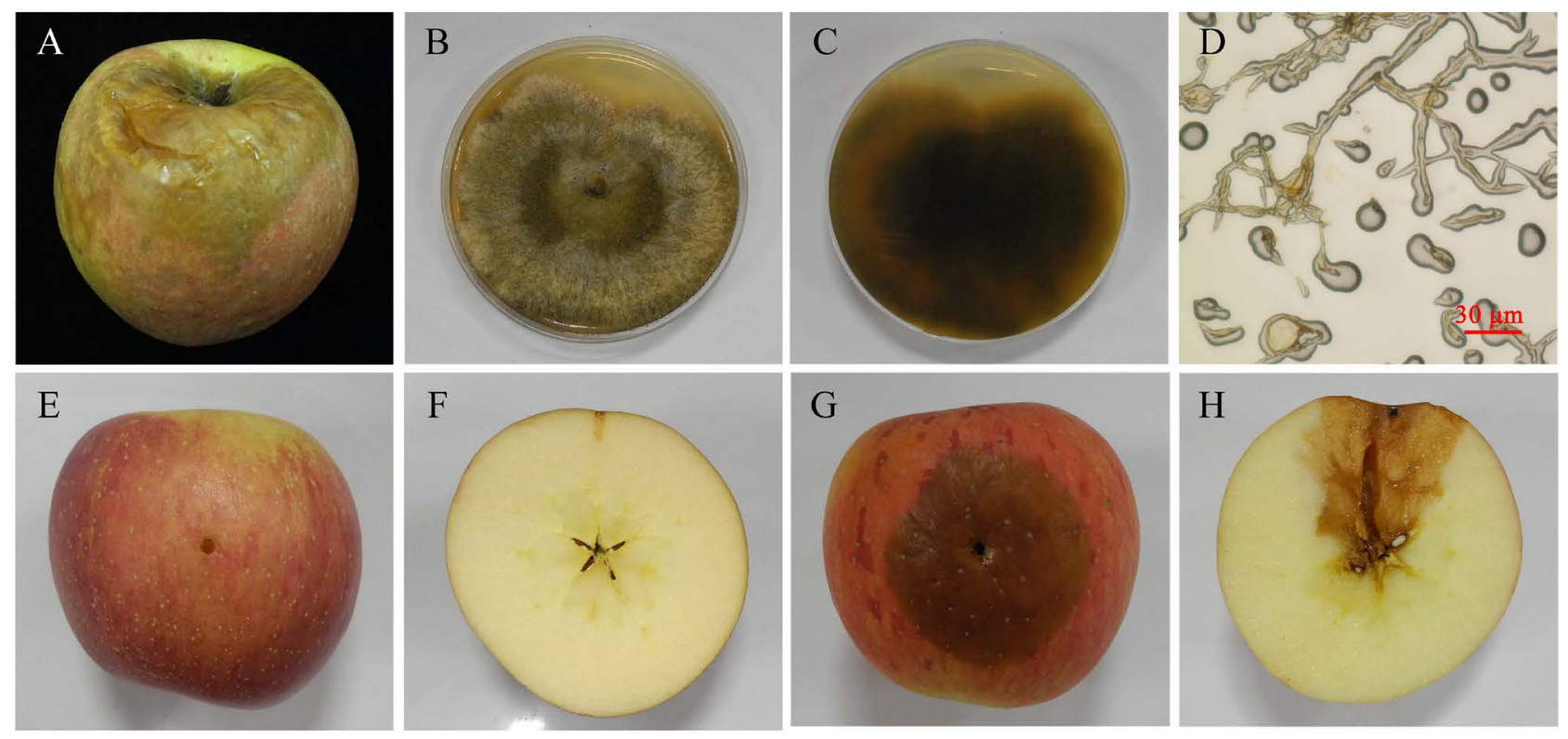

Figure 1. Disease symptom, colony, and morphological characteristics of isolated Diaporthe phaseolorum var. caulivora from apple. (A) Disease symptom on an apple naturally infected by D. phaseolorum var. caulivora; (B-C) The colonial morphology of D. phaseolorum var. caulivora on potato dextrose agar after 10 days of incubation at $25^{\circ} \mathrm{C}$; (B) photographed from the top of petri dish; (C) from the bottom of petri dish; (D)Conidia and hyphae were observed under an optical microscope with a $40 \times$ objective lens; (E-F) The surface (E) and cross section (F) of an apple inoculated with the sterile PDA plug as a negative control after 10 days of storage at $25^{\circ} \mathrm{C} ;(\mathrm{G}-\mathrm{H})$ The surface $(\mathrm{G})$ and cross section $(\mathrm{H})$ of an apple inoculated by D. phaseolorum var. caulivora after 10 days of storage at $25^{\circ} \mathrm{C}$.
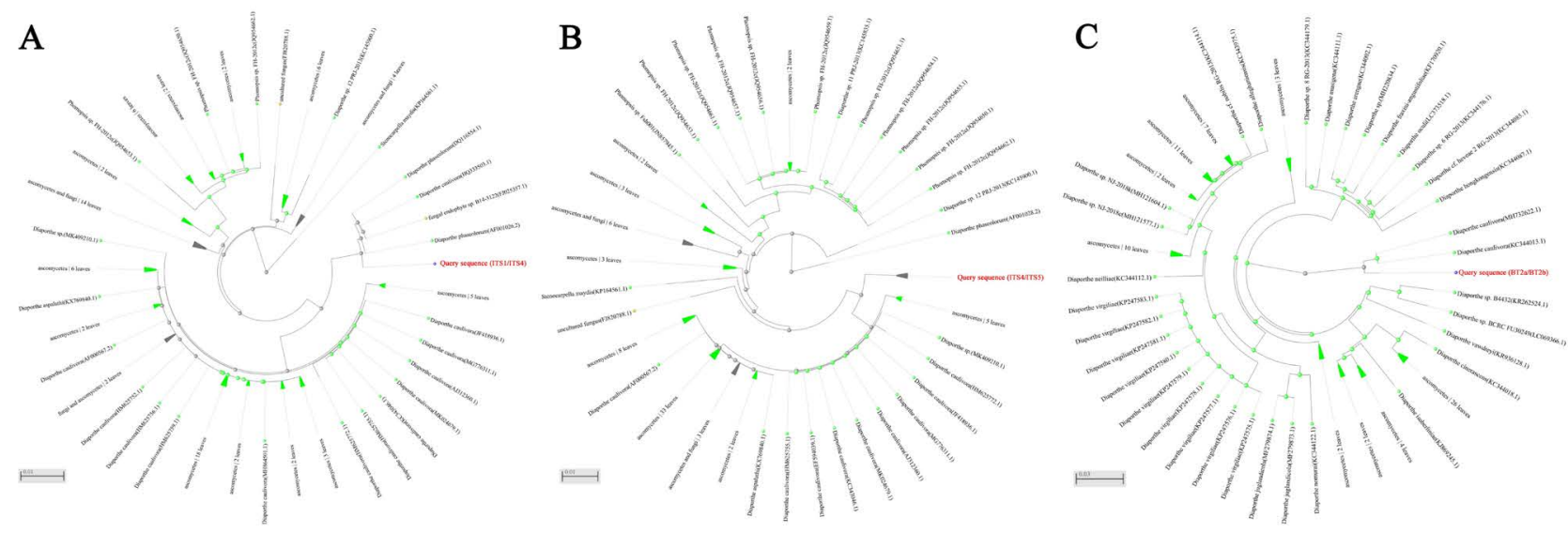

Figure 2. Blast results of the PCR products using universal primer pairs ITS1/ITS4 (A), ITS4/ITS5 (B), and BT2a/BT2b (C). ITS1/ITS4 and ITS4/ITS5 were used for DNA amplification of the ITS gene region. BT2a/BT2b was used for DNA amplification of beta-tubulin region. The distant tree was produced by BLAST pairwise alignments. Tree method was Fast Minimum Evolution. Max Seq Difference was 0.75 . The database was NCBI NR. Position of the query sequences in the phylogenetic tree was highlighted by red color.

Through the artificial infection test, all of the inoculated fruit show typical symptoms and lesion diameter ranged from 2.4 to $4.7 \mathrm{~cm}$ after 10 days of culturing. The negative control fruits remained healthy. The results indicated that the pathogen was highly pathogenic to apples. The re-isolated fungi had morphological characteristics that resembled the original isolates from infected ap- 
ples. The identity of these isolates was confirmed as D. phaseolorum var. caulivora by sequencing.

Diaporthe phaseolorum var. caulivorav, belonging to the class ascomycetes, was first found in Iowa in the 1940s which was responsible for soybean stem canker. In recent years, it has been reported in most soybean-growing regions in the world with high adaptability in a large number of hosts [9] [10] [11]. The fungus produces perithecia with asci and ascospores readily on infected senescent and dead plant tissues. Besides, it overwinters in harvest residues and seeds. The ascospores cause the first infections of young stems in spring and all subsequent infections. The fungus could maintain alive in hosts for at least 6-7 months [12]. On susceptible varieties, it can cause losses of up to $50 \%$ of the hosts. So far, the disease can be managed by suitable crop rotations, by culturing resistant varieties, and by appropriate fungicides, such as benzimidazoles. The findings in this study could provide some information for precisely controlling postharvest apple fruit rots.

\section{Conclusion}

A causal agent for brown rots of "Red Fuji" apples was isolated and identified by morphological characteristics and molecular identification. To our knowledge, this is the first report of $D$. phaseolorum var. caulivora causing postharvest rot on apple fruit in Zhejiang province, China.

\section{Acknowledgements}

This research was financially supported by the Zhejiang Provincial Natural Science Foundation of China (LY19C200010 and LY18C150009) and the Master Innovation Program of Zhejiang Provincial First-Class Biological Disciplines.

\section{Conflicts of Interest}

The authors declare no conflicts of interest regarding the publication of this paper.

\section{References}

[1] Johnson, R.D., Johnson, L., Kohmoto, K., Otani, H., Lane, C.R. and Kodama, M. (2000) A Polymerase Chain Reaction-Based Method to Specifically Detect Alternaria alternata Apple Pathotype ( $A$. Mali), the Causal Agent of Alternaria Blotch of Apple. Phytopathology, 90, 973-976. https://doi.org/10.1094/PHYTO.2000.90.9.973

[2] Mohammed, M., Bridgemohan, P., Mohamed, M.S., Bridgemohan, R.S.H. and Mohammed, Z. (2017) Postharvest Physiology and Storage of Golden Apple (Spondias cythera sonnerat or Spondias dulcis forst): A Review. Journal of Food Processing \& Technology, 8, 12. https://doi.org/10.4172/2157-7110.1000707

[3] Coton, M., Bregier, T., Poirier, E., Debaets, S., Arnich, N., Coton, E. and Dantigny, P. (2020) Production and Migration of Patulin in Penicillium expansum Molded Apples during Cold and Ambient Storage. International Journal of Food Microbiology, 313, Article ID 108377. https://doi.org/10.1016/j.ijfoodmicro.2019.108377

[4] Alwakeel, S.S. (2013) Molecular Identification of Isolated Fungi from Stored Apples 
in Riyadh, Saudi Arabia. Saudi Journal of Biological Sciences, 20, 311-317. https://doi.org/10.1016/j.sjbs.2013.05.002

[5] Singh, D. and Sharma, R.R. (2018) Chapter 1: Postharvest Disease of Fruits and Vegetables and Their Management. Postharvest Disinfection of Fruits and Vegetables, 1, 1-52. https://doi.org/10.1016/B978-0-12-812698-1.00001-7

[6] Lai, T.F., Bai, X.L., Wang, Y., Zhou, J.Y., Shi, N.N. and Zhou, T. (2015) Inhibitory Effect of Exogenous Sodium Bicarbonate on Development an Pathogenicity of Postharvest Disease Penicillium expansum. Scientia Horticulturae, 187, 108-114. https://doi.org/10.1016/j.scienta.2015.03.010

[7] Weir, B.S., Johnston, P.R. and Damm, U. (2012) The Colletotrichum gloeosporioides Species Complex. Studies in Mycology, 73, 115-180.

https://doi.org/10.3114/sim0011

[8] Sun, S.L., Van, K.J., Kim, M.Y., Lee, Y.W. and Lee, S.H. (2012) Diaporthe phaseolorum var. caulivora, a Causal Agent for Both Stem Canker and Seed Decay on Soybean. The Plant Pathogen Journal, 28, 55-59.

https://doi.org/10.5423/PPJ.NT.10.2011.0194

[9] Danggomen, A., Visarathanonth, N., Manoch, L. and Piasai, O. (2013) Morphological Studies of Endophytic and Plant Pathogenic Phomopsis liquidambaris and Diaporthe phaseolorum ( $P$. phaseoli anamorph) from Healthy Plants and Diseased Fruit. Thai Journal of Agricultural Science, 46, 157-164.

http://www.thaiagj.org/images/stories/Journal online/2013/3/07-tj-agr-1013-66-p1 57-164.pdf

[10] Dissanayake, A.J., Liu, M., Zhang, W., Chen, Z., Udayanga, D., Chukeatirote, E., Li X.H., Yan, J.Y. and Dyde, K.D. (2015) Morphological and Molecular Characterization of Diaporthe Species Associated with Grapevine Trunk Disease in China. Fungal Biology, 119, 283-294. https://doi.org/10.1016/j.funbio.2014.11.003

[11] Dissanayake, A.J., Phillips, A.J.L., Hyde, K.D., Yan, J.Y. and Li, X.H. (2017) The Current Status of Species in Diaporthe. Mycosphere, 8, 1106-1156. https://doi.org/10.1016/j.funbio.2014.11.003

[12] Grijalba, P. and Ridao, A.D.C. (2012) Survival of Diaporthe phaseolorum var. caulivora (Causal Agent of Soybean Stem Canker) Artificially Inoculated in Different Crop Residues. Tropical Plant Pathology, 37, 271-274.

https://doi.org/10.1590/S1982-56762012000400006 